penicillamine..$^{3,14-19}$ Most reports of $\mathrm{D}$-penicillamineinduced pemphigus are in patients with rheumatoid arthritis.

\section{REFERENCES}

1. Brenner $S$, Wolf $R$, Ruocco V. Drug-induced pemphigus I: a survey. Clin Dermatol 1993;11:501-4.

2. Levy RS, Fisher M, Alter JN. Penicillamine: review and cutaneous manifestations. J Am Acad Dermatol 1983;8:548-58.

3. McGovern TW, Bennion SD. Diffuse blisters and erosions in a patient with limited scleroderma. Arch Dermatol 1997;133:499504.

4. Piamphongsant $T_{r}$ Ophaswongse $S$. Treatment of pemphigus. Int J Dermatol 1991;30:139-46.

5. Walton S, Keczkes K, Robinson AE. A case of penicillamineinduced pemphigus, successfully treated by plasma exchange. Clin Exp Dermatol 1987;12:275-6.

6. Ahmed AR, Graham J, Jordon RE, Provost TT.Pemphigus: current concepts. Ann Intern Med 1980;92:396-405.

7. Korman NJ, Eyre RW, Zone J, Stanley JR. Drug-induced pemphigus: autoantibodies directed against the pemphigus antigen complexes are present in penicillamine and captopril-induced pemphigus. J Invest Dermatol 1991;96:273-6.

8. Mobinin N, Ahmed AR. Immunogenetics of drug-induced bullous diseases. Clin Dermatol 1993;11:449-60.

9. Mutasim DF, Pelc NJ, Anhalt GJ. Drug-induced pemphigus. Dermatol Clin 1993;11:463-71.
10. Ho VC, Stein HB, Ongley RC, McLeod A. Penicillamine induced pemphigus.J Rheumatol 1985;12:583-6.

11. Zone J, Ward J, Boyce E, Schupbach C. Penicillamine-induced pemphigus. JAMA 1982;247:2705-7.

12. Katz AL, Nashel DJ, Goard CP, Bauer H. Pemphigus vulgaris and lymphoma in a patient with scleroderma. South Med J 1979;72: 1463-6.

13. Woscoff EA, Remondino G, Jaimovich $L$, Berengust $G$, Rios A. Progressive systemic sclerosis and pemphigus vulgaris. J Am Acad Dermatol 1989;21:142-4.

14. Asboe-Hansen G. Treatment of generalized scleroderma with inhibitors of connective tissue formation. Acta Derm Venereol (Stockh) 1975;55:461-5.

15. Davies MG, Holt P. Pemphigus in a patient treated with penicillamine for a generalized morphea. Arch Dermatol 1976;112: 1308-9.

16. From E, Frederiksen P. Pemphigus vulgaris following D-penicillamine. Dermatologica 1976;152:358-62.

17. Kristensen $\mathrm{JK}$, Wadskov S. Penicillamine-induced pemphigus foliaceus. Acta Derm Venereol (Stockh) 1977;57:69-71.

18. Peñas PF, Buezo GF, Carvajal I, Dauden E, Lopez A, Diaz LA. DPenicillamine-induced pemphigus foliaceus with autoantibodies to desmoglein-1 in a patient with mixed connective tissue disease. J Am Acad Dermatol 1997;37:121-3.

19. Steen VD, Blair $S$, Medsger TA. The toxicity of $D$-penicillamine in systemic sclerosis. Ann Intern Med 1986;104:699-705.

\title{
Bacillary angiomatosis by Bartonella quintana in an HIV-infected patient
}

\author{
Raquel Santos, ${ }^{\mathrm{a}}$ Orlando Cardoso, ${ }^{\mathrm{b}}$ Paulo Rodrigues, ${ }^{\mathrm{b}}$ Jorge Cardoso, ${ }^{\mathrm{a}}$ João Machado, ${ }^{\mathrm{b}}$ \\ Ana Afonso, ${ }^{\mathrm{c}}$ Fátima Bacellar, ${ }^{\mathrm{d}}$ Eric Marston, ${ }^{\mathrm{e}}$ and Rui Proença ${ }^{\mathrm{b}}$ Lisbon, Portugal, \\ and Atlanta, Georgia
}

\begin{abstract}
Bacillary angiomatosis and bacillary peliosis are opportunistic infections caused by Bartonella henselae and Bartonella quintana, which occur in patients with late-stage infection. We report a case of bacillary angiomatosis in an HIV-infected patient with skin, bone, and probably liver involvement, The identification of the agent ( $B$ quintana) was done by polymerase chain reaction in the skin specimen. The patient had complete regression of all lesions after a 6-month regimen of oral erythromycin. (J Am Acad Dermatol 2000;42:299-301.)
\end{abstract}

\footnotetext{
From the Departments of Dermatology and Venereology,a Infectious Diseases, ${ }^{b}$ and Pathology, ${ }^{\mathrm{c}}$ Hospital Curry Cabral, Lisbon, Centro de Estudos de Vectores e Doencas Infecciosas/Instituto Nacional de Saúde Dr Ricardo Jorge, Águas de Moura, and Division of Viral and Rickettsial Diseases, Centers for Disease Control and Prevention, Atlanta.e

Reprint requests: Raquel Santos, Serviço de Dermatologia, Hospital de Curry Cabral, Rua da Beneficiência, 1069-166 Lisboa, Portugal. Copyright $\odot 2000$ by the American Academy of Dermatology, Inc.

0190-9622/2000/\$12.00+0 16/54/102645
}

B acillary angiomatosis and bacillary peliosis are opportunistic infections that were first recognized in 1983 by Stoler et al, ${ }^{1}$ at the beginning of the AIDS epidemic. The causative organisms are Bartonella benselae and B quintana, and the infection occurs in severely immunocompromised patients with late stage HIV infection. The manifestations of Bartonella infection in the 


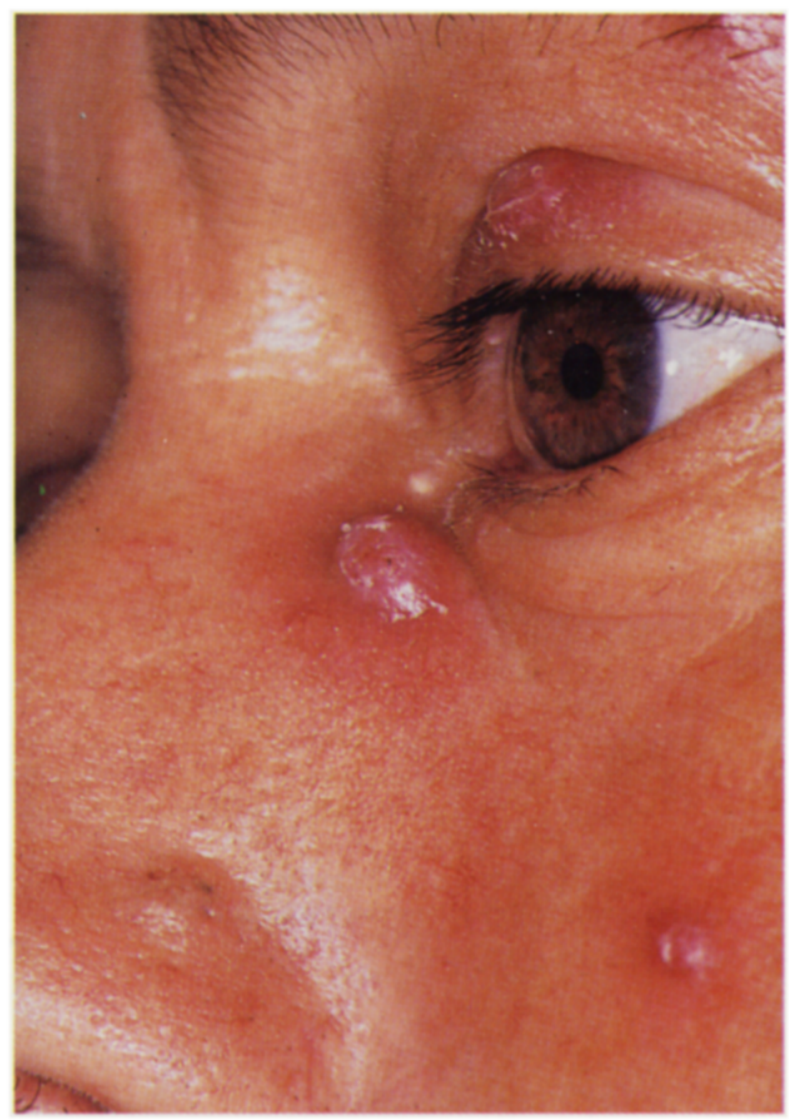

Fig 1. Multiple erythematous-violaceous cutaneous nodules on face.

immunocompromised host are diverse and sometimes nonspecific, which can result in failure to diagnose this infection. Bacillary angiomatosis is a systemic disease, and cutaneous lesions may be accompanied by brain, bone, lymph node, gastrointestinal tract, respiratory tract, and bone marrow involvement. Bacillary angiomatosis can be lifethreatening if untreated.

\section{CASE REPORT}

A 50-year-old man, HIV-1 positive since 1994, was receiving antiretroviral triple therapy with zidovudine (AZT), lamivudine (3TC), and indinavir, and prophylaxis with trimethoprim-sulfamethoxazole. He had fever for 8 weeks $\left(39^{\circ} \mathrm{C}\right)$, weight loss, and several erythematous-violaceous cutaneous nodules on the face (Fig 1), oral mucosa, trunk, and arms. There were also painful subcutaneous masses on the arms and limbs. He was severely immunocompromised (CD 4 cell count $<10$ cells $/ \mathrm{mm}^{3}$, and HIV viral load of 81,000 copies $/ \mathrm{mL}$ [5.25 log]). Other laboratory studies showed leukocyte count $2200 \mathrm{cells} / \mathrm{mm}^{3}$, hemoglobin $9.1 \mathrm{~g} / \mathrm{dL}$, hematocrit $27.1 \%$, and platelets $291,000 / \mathrm{mm}^{3}$. Erythrocyte sedimentation

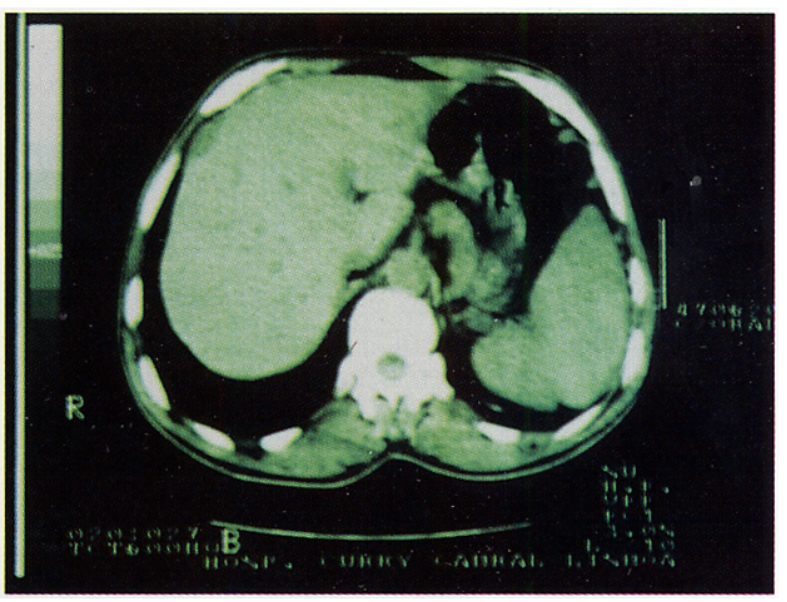

Fig 2. Abdominal CT scan shows hypodense liver lesion suggestive of bacillary peliosis (arrow).

rate was $117 \mathrm{~mm} / \mathrm{h}$. Liver function test results and chest radiograph were within normal limits. There was bone involvement with several lytic lesions visible on plain film and easily identified with technetium scanning. An abdominal computed tomographic scan showed a hypodense liver lesion suggestive of bacillary peliosis (Fig 2). A liver biopsy was not performed. The clinical diagnosis of bacillary angiomatosis was confirmed by histopathologic examination of the skin lesions and Warthin-Starry staining. Blood cultures performed on EDTA blood tubes and inoculated onto chocolate agar were negative. Serology using indirect immunofluorescence for Bartonella species was negative. The identification of the agent, $B$ quintana, was accomplished by means of polymerase chain reaction (PCR) in the skin specimen (VRZB/CDC, Atlanta). The domestic cat owned by the patient was negative for Bartonella spp (blood culture and serology). PCR was not performed on blood from the cat.

The patient was treated with oral erythromycin, 2 $\mathrm{g} /$ day for 6 months, with complete regression of cutaneous, bone, and hepatic lesions. He continued antiretroviral triple therapy (AZT, 3TC, indinavir) and prophylactic therapy with trimethoprim-sulfamethoxazole. After 1 year of follow-up the patient is well (CD4 cell count 190 cells $/ \mathrm{mm}^{3}$ and HIV viral load <500 copies/mL).

\section{DISCUSSION}

Bacillary angiomatosis and bacillary peliosis are opportunistic infections caused by $B$ benselae and $B$ quintana that occur in patients with late-stage HIV infection. Cutaneous involvement is the most frequently recognized manifestation, but can appear as diverse angiomatous lesions. ${ }^{2,3}$ The patients can also 
present with subcutaneous nodules or deep soft tissue masses.

The two above-mentioned Bartonella spp are equally likely to cause cutaneous bacillary angiomatosis, but $B$ quintana is responsible for most cases of subcutaneous infection, deep soft-tissue disease, and lytic bone lesions. To date peliosis hepatis and lymph node involvement have been associated exclusively with $B$ benselae infection. 4,5 In the past, $B$ quintana (formerly called Rocbalimaea quintana or Rickettsia quintana) was known as the cause of trench fever. Transmission occurred through the bite of the human body louse. A study in Seattle showed that those at greater risk are homeless persons of low socioeconomic status and those with exposure to head and body lice. ${ }^{6}$ Koehler, Glaser, and lappero ${ }^{7}$ documented that the domestic cat serves as a major reservoir for $B$ benselae, and that the cat flea is a potential vector. Our patient had skin, bone, and probable liver involvement, findings not typically described in the literature associated with $B$ quinıarı infection. Although he had a cal, its serology and blood culture were negative for Bartonella sp. The source of bacillary angiomatosis caused by $B$ quintana remains unknown, and the only recom- mendation for preventing infection is to avoid contact with head and body lice, known vectors of $B$ quintana.

\section{REFERENCES}

1. Stoler MH, Bonfiglio TA, Steigbigel RT, Pereira M. An atypical subcutaneous infection associated with acquired immune deficiency syndrome. Am J Clin Pathol 1983;80:714-8.

2. Koehler JE, Tappero JW. Aids commentary: bacillary angiomatosis and bacillary peliosis in patients infected with human immunodeficiency virus. Clin Infect Dis 1993;17:612-3.

3. Schwartz RA, Nychay SG, Janniger CK, Lambert WC. Bacillary angiomatosis: presentation of six patients, some with unusual features. Br J Dermatol 1997;136:60-5.

4. Koehler JE, Sanchez MA, Garrido CS, Whitfeld JM, Chen FM, Berger TG, et al. Molecular epidemiology of Bartonella infections in patients with bacillary angiomatosis-peliosis. $\mathrm{N}$ Engl $J$ Med 1997;337:1876-83.

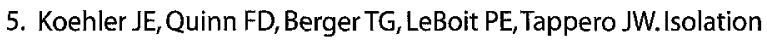
of Rochalimaea species from cutaneous and osseous lesions of bacillary angiomatosis. N Engl J Med 1992;327:1625-31.

6. Spach DH, Kanter AS, Dougherty MJ, Larson AM, Coyle MB, Brenner DJ, et al. Bartonella (Rochalimaea) quintana bacteremia in inner-city patients with chronic alcoholism. $\mathrm{N}$ Engl J Med 1995;332:424-8.

7. Koehler JE, Glaser CA, Tappero JW. Rochalimaea henselae infection: a new zoonosis with the domestic cat as reservoir. JAMA 1994;271:531-5. 